\title{
The Authorities of Province and District Governments Regarding Spatial Planning in Aceh
}

\author{
Arnita*, Faisal A. Rani, llyas Ismail and Efendi \\ Faculty of Law, Universitas Syiah Kuala, Jl. Putroe Phang No.1 Darussalam, Banda Aceh, 23111, Aceh, \\ Indonesia
}

\begin{abstract}
Article 7 of the Law Number 11, 2006 on Aceh Governance states that the Aceh Province and districts or municipalities Governments have the authority to regulate and manage government affairs in all public sectors except for government affairs which are under the authority of the Government. It is further stated that the central authority includes government affairs of national issues that are foreign policy, defense, security, judiciary, monetary and fiscal matters, and certain affairs in the field of religion. It can be concluded that the Job Creation Act in its approach contradicts the principle of autonomy because the regulation is centralized.
\end{abstract}

Keywords: Aceh, province governments, spatial planning.

\section{INTRODUCTION}

Aceh Province is one of the provinces in Indonesia that is given special autonomy as a middle way solution to realize the welfare of the people and reduce armed conflict that wants Aceh to stand alone as an independent and sovereign state separate from the Unitary State of the Republic of Indonesia. The special autonomy was first granted through Law Number 18 of 2001 concerning Special Autonomy for the Special Region of the Province of Nanggroe Aceh Darussalam. However, in reality, what happened in Aceh the presence of this law has not succeeded in suppressing the armed resistance carried out by the Free Aceh Movement (GAM).

The earthquake and tsunami that hit Aceh in 2004 also had an impact on peace in the province. GAM and the Government of Indonesia agreed on peace talks in Helsinki, Finland which issued a Helsinki Memorandum of Understanding (MoU). The agreement finally caused to Law No. 11 of 2006 (hereinafter UUPA) on the Government of Aceh which is a special autonomy law for Aceh which has been in force until now.

Article 7 of the Law Number 11, 2006 concerning UUPA The authority of the Aceh Government according to UUPA is to regulate and manage government affairs in all public sectors except for government affairs which are the affairs of the Government, namely the fields of foreign policy, defense, security, judicial, monetary and national fiscal, and certain affairs in the religious field. If you refer to

*Address correspondence to this author at the Faculty of Law, Universitas Syiah Kuala JI. Putroe Phang No.1 Darussalam Banda Aceh, 23111, Aceh, Indonesia; Tel: +6285220128297; E-mail: arnita_jamil@yahoo.co.id these provisions, other than those which are the authority of the Government, it is the authority of the Government of Aceh, including those related to spatial planning.

The enactment of Law Number 11 of 2020 concerning Job Creation changes the provisions on spatial planning which were previously regulated by law number 26 of 2007 . The issuance of this law cuts down the authority of local governments in spatial planning. In the work copyright law, the authority for spatial planning is in the hands of the central government as regulated in Article 9 paragraph (1). Based on the background above, the author wants to discuss how the authority of the provincial and district/city governments is related to the decentralization of spatial planning in Aceh Province.

\section{LITERATURE REVIEW}

Within the framework of regional autonomy, regions are given full authority to manage their households, with their capabilities, including in regional spatial planning. Sri Soemantri thinks that the delegation of authority from the Central Government to the Autonomous Region is not something that is stipulated in its constitution, but because the problem is the essence of a unitary state (Soemantri, 1981). So all activities within the framework of the state remain within the bonds of the unitary state, including a quo regional autonomy (Basah, 1986).

The granting of autonomy to regions is so that regions can actively succeed in the implementation of national development, regional autonomy is the freedom to determine and advance special interests with their finances, determine their laws, and form their government (Wajong, 1975). 
The granting of special autonomy to several provinces in Indonesia, such as the granting of special autonomy to the province of Aceh, is a manifestation of the aspirations of the people. Regional autonomy is the right, authority, and obligation of autonomous regions to regulate and manage their government affairs and the interests of the local community in the Unitary state system of the Republic of Indonesia (NKRI).

Decentralization is the transfer of government affairs by the central government to autonomous regions based on the principle of autonomy. Decentralization is expected to be able to encourage local government and local community empowerment (empowering) and strengthening (strengthening). The implementation of decentralization will also provide the following benefits: 1) local governments will be more understand the needs and needs of the area/desire of the local community (better knowledge of local demands); 2) enable the government to be better able to respond or respond to various challenges and demands from the community (ability to respond to local cost variations); 3) increasing public participation in determining the course of government (increased scope for community participation), and 4) close the distance between the community and the government so that the community feels the benefits derived from the costs incurred (closer correspondence between costs and benefits). It is with these considerations that decentralization is implemented in countries in the world today. The conditions of each region have different characteristics from each other which to a certain degree cannot be generalized (Dawud, 2016).

Government authority delegated to the regions in the context of decentralization must be accompanied by the delivery and transfer of financing, facilities, and infrastructure, as well as human resources following the delegated authority. Government authority delegated to the Governor in the context of deconcentration must be accompanied by financing following the delegated authority. In the administration of government authority which is delegated and/delegated to the regions/governors has the authority to manage it starting from financing, licensing, planning, implementation, and evaluation following government standards, norms, and policies (Bratakusumah, 2004).

Spatial planning is a process system for spatial planning, space utilization, and space utilization control. The linkage between one regional spatial condition and another regional spatial condition regarding spatial planning certainly requires the coordination of the government, both central government, provincial government, and district/city local government.

Regarding spatial planning, apart from being regulated by Law Number 26 of 2007 concerning Spatial Planning, spatial planning is also regulated in several other laws and regulations, such as Law Number 23 of 2014 concerning Regional Government. Especially for Aceh Province regarding spatial planning, there is also a regulation in Law Number 11 of 2006 concerning Aceh Government.

\section{METHODS}

This research is normative legal research which is carried out by searching and finding sources of law that are relevant to the subject matter under study. In this case, various available legal authorities will be used, primary authorities, secondary legal authorities, and tertiary legal authorities.

\section{GOVERNMENT AUTHORITY FOR SPATIAL PLANNING}

The regulation on spatial planning related to the authority has been regulated in Law Number 26 of 2007 by spatial planning, the authority referred to here is the authority to control the use of space by both the Central Government and the Provincial and District/City Governments. The government's authority in spatial planning includes the authority of the central government in controlling the use of space throughout the territory of the Unitary State of the Republic of Indonesia. the government's authority includes the authority to decide on the use of space, both government and private use (Mandey, 2015).

Article 8 of the Spatial Planning Law regulates the Government's authority in spatial planning which includes:

1. The Government's authority in implementing spatial planning includes:

a. regulation, guidance, and supervision of the implementation of spatial planning for national, provincial, and district/city spatial planning, as well as on the implementation of spatial planning for national, provincial, and district/city strategic areas;

b. implementation of spatial planning of the national territory; 
c. implementation of national strategic area spatial planning; and

d. cooperation in spatial planning between countries and facilitation of cooperation in spatial planning between provinces.

2. Government authorities in implementing national spatial planning include:

a. national regional spatial planning;

b. utilization of national territory space; and

c. controlling the use of space in the national territory.

3. The authority of the Government in implementing the spatial management of the national strategic area includes:

a. determination of national strategic areas;

b. national strategic area spatial planning;

c. utilization of national strategic area space; and

d. controlling the use of space in the national strategic area.

4. The implementation of space utilization and control over the use of space in the national strategic area as referred to in paragraph (3) letter $\mathrm{c}$ and letter $\mathrm{d}$ can be carried out by the regional government through deconcentration and/or co-administration.

5. In the framework of implementing spatial planning, the Government has the authority to formulate and stipulate guidelines for the field of spatial planning.

6. In the exercise of the authority as referred to in paragraph (1), paragraph (2), paragraph (3), paragraph (4), and paragraph (5), the Government:

a. disseminate information related to:

1) general plans and detailed spatial plans in the framework of implementing national spatial planning;

2) the direction of zoning regulations for the national system which is prepared in the context of controlling the utilization of national territory space; and
3) guidelines for spatial planning;

b. establish minimum service standards in the field of spatial planning.

Furthermore, Article 9 states:

1. The implementation of spatial planning is carried out by a Minister.

2. The duties and responsibilities of the Minister in the implementation of spatial planning as referred to in paragraph (1) include:

a. regulation, development, and supervision of spatial planning;

b. implementation of national spatial planning; and

c. coordination of cross-sectoral, cross-regional, and cross-stakeholder spatial planning.

The explanation of Law No. 26 of 2007 provides an explanation related to the authority of the Government in the field of spatial planning in the country's border areas is spatial planning cooperation between countries involving other countries so that there are aspects of relations between countries which are the authority of the Government. space in the state border area. The granting of authority to the Government in facilitating inter-provincial spatial planning cooperation is intended so that spatial planning cooperation provides optimal benefits for all cooperating provinces.

The government is also authorized to use space and control the spatial use of national strategic areas, including aspects related to strategic values that form the basis for determining strategic areas. the basis for determining strategic areas. Following the provisions of laws and regulations, deconcentration is given to the Governor as a representative of the Government in the region, while assistance tasks can be given to the Governor and the Regent/Mayor.

Another government authority is to formulate guidelines for the field of spatial planning. What is meant by "guidelines in the field of spatial planning" shall also include norms, standards, and manuals in the field of spatial planning. Which include standards in the field of spatial planning are technical provisions as a reference in the implementation of spatial planning. Included in the manual for spatial planning are implementation instructions and technical instructions as operational references in the implementation of spatial planning. 
Another government authority is related to the preparation of minimum service standards in the field of spatial planning. Minimum service is the right and obligation of recipients and service providers to ensure equal access and quality of basic services to the community. Minimum service standards in the field of spatial planning are prepared by the Government and applied to all provincial governments and district/city governments to ensure the quality of basic services to the community equally in the context of spatial planning.

Government Regulation number 15 of 2010 concerning the implementation of spatial planning, in the article, states that spatial planning arrangements by the government include the preparation and determination of:

a. National Spatial Planning Plan and implementing regulations of the law on spatial planning stipulated by government regulation;

b. island/archipelagic spatial plan and national strategic area spatial plan stipulated by presidential regulation; and

c. guidelines for the field of spatial planning stipulated by a Ministerial regulation. In the explanation, it is stated that the guidelines for the field of spatial planning include technical standards and manuals for the field of spatial planning.

In 2020 the government issued Law Number 11 of 2020 concerning Job Creation. With this law, it is hoped that it will be able to absorb the widest possible Indonesian workforce, for this reason, it is necessary to adjust various regulatory aspects related to the convenience, protection, and empowerment of cooperatives and micro, small and medium enterprises, improvement of the investment ecosystem, and project acceleration. The national strategy, including increasing the protection and welfare of workers. One of the adjustment settings is related to spatial planning.

These changes include the government's authority as regulated in Article 8 of Law Number 26 of 2007. Article 17 point 3 of the Job Creation Law states that the provisions of Article 8 are amended so that it reads as follows:

Article 8

1. The authority of the Central Government in the implementation of spatial planning includes: a. The setting, fostering, and supervising the implementation of spatial planning for the national, provincial, and district/city areas, as well as on the implementation of spatial planning for national strategic areas;

b. providing technical assistance for the preparation of provincial, regency/municipal spatial plans, and detailed spatial plans;

c. technical guidance in the preparation of spatial planning activities provincial area, regency/municipal spatial planning plan, and detailed spatial planning plan;

d. implementation of spatial planning of the national territory;

e. implementation of spatial planning for national strategic areas; and

f. cooperation in spatial planning between countries and facilitating cooperation in spatial planning between provinces.

2. The authority of the Central Government in implementing national spatial planning includes:

a. national spatial planning;

b. utilization of national territory space; and

c. control of the use of illegal wildlife in the national territory.

3. The authority of the Central Government in implementing the spatial management of national strategic areas includes:

a. determination of national strategic areas;

b. national strategic area spatial planning;

c. utilization of national strategic area space; and

d. controlling the use of space in the national strategic area.

4. In the framework of implementing spatial planning, the Central Government has the authority to formulate and stipulate guidelines for the field of spatial planning.

5. In the exercise of the authority as referred to in paragraph (1), paragraph (2), paragraph (3), and paragraph (4), the Central Government: 
a. disseminate information related to:

A. general plans and detailed spatial plans in the framework of implementing national spatial planning; and

B. guidelines for spatial planning.

b. establish minimum service standards in the field of spatial planning.

6. Further provisions regarding the authority to administer spatial planning shall be regulated in a Government Regulation.

The explanation of the provisions of Article 8 paragraph (1) letter $f$ states that cooperation in spatial planning between countries involves other countries so that there are aspects of relations between countries which are the authority of the Government. The granting of authority to the Government in facilitating inter-provincial spatial planning cooperation is intended so that spatial planning cooperation provides optimal benefits for all cooperating provinces.

Regarding the dissemination of information by the central government, among others, through electronic media, print media, and other communication media, as a form of embodiment of the principle of openness in the implementation of spatial planning.

Other amendments from Law No. 26 of 2007 are made to the provisions of Article 9. The provisions of Article 9 were amended to read as follows:

Article 9

1. The implementation of spatial planning is carried out by the Central Government.

2. Further provisions regarding duties and responsibilities the implementation of spatial planning as referred to in paragraph (1) shall be regulated in a Government Regulation.

The explanation to Article 9 paragraph (1) is that the implementation of spatial planning by the Central Government includes, among others, regulation, guidance, supervision of cross-sectoral, cross-regional, and cross-stakeholder spatial planning which can be carried out with a participatory approach through committees or forums.

From the sound of the provisions of the Employment Creation Act Article 17 point 3, it is explicitly stated that the implementation of spatial planning is carried out by the Central Government followed by provisions regarding the duties and responsibilities of spatial planning regulated in a Government Regulation, while the old provisions related to the implementation of spatial planning are carried out by a minister who is in charge of and responsible for the regulation, guidance, and supervision of spatial planning, implementation of national spatial planning and coordination of crosssectoral, cross-regional, and cross-stakeholder spatial planning as stipulated in Article 9 of Law no. 26 of 2007.

\section{PROVINCIAL AUTHORITY FOR SPATIAL PLANNING}

The Constitution of the State of Indonesia states that Indonesia is a unitary state in the form of a republic. Furthermore, Article 18 paragraph (1) of the 1945 Constitution states that "The Unitary State of the Republic of Indonesia is divided into provincial areas and provincial areas are divided into regencies and cities, where each province, district, the city has a regional government which is regulated by law. -law". As a follow-up to these provisions, regional governments are given autonomy or regions have the authority to regulate and manage their households within the framework of a unitary state.

One of the authorities possessed by the regions, both provincial and regency/municipal, is related to the field of spatial planning. Law Number 26 of 2007 gives authority to the Province in terms of spatial planning in Article 10.

1. The authority of the provincial government in implementing spatial planning includes:

a. regulation, guidance, and supervision of the implementation of spatial planning for provincial and district/municipal areas, as well as on the implementation of spatial planning for provincial and district/municipal strategic areas

b. implementation of spatial planning in the province;

c. implementation of provincial strategic area spatial planning; and

d. interprovincial spatial planning cooperation and facilitation of inter-district/city spatial planning cooperation. 
2. The authority of the provincial government in implementing the spatial management of the province as referred to in paragraph (1) letter $b$ includes:

a. provincial spatial planning;

b. use of provincial space; and

c. controlling the use of provincial space.

3. In the spatial planning of the provincial strategic area as referred to in paragraph (1) letter $\mathrm{c}$, the provincial government shall implement:

a. determination of provincial strategic areas;

b. provincial strategic area spatial planning;

c. utilization of provincial strategic area space; and

d. controlling the spatial use of provincial strategic areas.

4. The implementation of space utilization and control of the spatial use of the provincial strategic area as referred to in paragraph (3) letter $c$ and letter $d$ can be carried out by the district/municipality regional government through co-administration tasks.

5. In the framework of implementing the spatial management of the province, the provincial government may prepare guidelines for the implementation of the spatial management sector at the provincial and district/city levels.

6. In the exercise of the authority as referred to in paragraph (1), paragraph (2), paragraph (3), paragraph (4), and paragraph (5), the provincial government:

a. disseminate information related to:

1) general plan and detailed spatial plan in the framework of implementing provincial spatial planning;

2) directions for zoning regulations for the provincial system that are drawn up in the context of controlling the use of provincial space; and

3) implementation instructions in the field of spatial planning; b. implement minimum service standards in the field of spatial planning.

7. If the provincial government cannot meet the minimum service standards in the field of spatial planning, the Government takes steps to resolve it by the provisions of the legislation.

The enactment of the Job Creation Law brings changes to the authority possessed by the Province in the field of spatial planning. Article 17 point 5 of the law states that "the provisions of Article 10 are amended so that they read as follows:

"The authority of the Provincial Government is carried out by the norms, standards, procedures, and criteria set by the Central Government in the implementation of spatial planning, including:

a. The setting, fostering, and supervising the implementation of spatial planning in the provinces and regencies/municipalities

b. Implementation of provincial spatial planning; and

c. cooperation in spatial planning to facilitate cooperation between districts/cities."

When compared with the spatial planning provisions contained in Law No. 26 of 2007, the provincial government's authority has been removed with the following matters:

1. The authority to regulate, foster, and supervise the implementation of provincial spatial planning must be made by the norms, standards, procedures, and criteria set by the Central Government.

2. Authority for regulation, guidance, and supervision as well as the implementation of spatial planning for provincial strategic areas. Provincial strategic areas are areas where spatial planning is prioritized because they have a very important influence within the scope of the province on the economy, social, culture, and/or environment.

3. Authority for area determination, regional spatial planning, regional space utilization, and control of provincial strategic area spatial use.

4. Provincial authority in the context of compiling guidelines for the implementation of spatial planning at the provincial and district/city levels. 
5. The authority to make settlements so that district/city governments can meet minimum service standards in the field of spatial planning.

If referring to the 1945 Constitution Article 18 paragraph (2) which states "The provincial, district and city governments regulate and manage their government affairs according to the principles of autonomy and co-administration". This provision confirms the regional government as an autonomous government unit within the Unitary State of the Republic of Indonesia. Autonomy always requires independence or freedom. It is not even an exaggeration to say that the essence of autonomy is independence, although it is not a form of freedom of an independent unit (zelfstandigheid not onafhankelijkheid) (Manan, 2002).

Judging from the various laws and regulations governing autonomy can be distinguished two main categories of autonomy politics that have been carried out or have been carried out, namely the tendency towards decentralization or centralization.

Decentralization means the delegation of government power from the central government to the regions to manage their households or to be given autonomy to become autonomous regions. Hogewert defines it as an acknowledgment or delegation of authority by lower public bodies to independently based on considerations of their interests make decisions on governance arrangements, as well as the structure of authority that occurs from it (Widodo, 2016). Decentralization can also be interpreted as the delegation of greater authority and responsibility to officials who lead lower governance units (Karnesih, 2004).

The provisions governing provincial authorities related to spatial planning as regulated in the Job Creation Law have been implemented to eliminate some of the authority possessed by the province. Thus, it can be concluded that the Job Creation Act in its approach uses the politics of autonomy more towards centralization than the tendency towards decentralization.

The Aceh Province is a province that is granted special autonomy and has the privileges as stipulated in Law Number 11 of 2006. If you look at the provisions concerning the authority of the Aceh Government, Law Number 11 of 2006 in Article 7 states that the Aceh Government and Regency/City have the authority to regulate and manage government affairs in all public sectors except for government affairs which are the authority of the Government. It is further stated that the central authority covers government affairs of a national nature, foreign policy, defense, security, judiciary, national monetary and fiscal matters, and certain affairs in the field of religion.

From these provisions, the authority given is closer to the residual power or open and arrangement doctrine (the concept of original power and residual power), that is, in addition to the authority determined as the authority of the central government, the remaining authority becomes the authority of the regional government. This is more towards decentralization.

Law Number 11 of 2006 also regulates spatial planning in Article 14 paragraph (1) which incorporates spatial planning, utilization, and supervision into mandatory affairs which are under the authority of the Aceh Government. When compared with the provisions of the Job Creation Law, this authority has been removed along with the abolition of the provisions of Article 10 of Law No. 26 of 2007 . It can be concluded that the provisions governing spatial planning in the work copyright law are contrary to the principle of autonomy because the regulation is centralized.

\section{Regency/City Authority for Spatial Planning}

The authority related to spatial planning in regency/municipal areas is regulated in the Job Creation Law as regulated in Article 11. The text of the article is as follows:

Article 11

1. The authority of the regency/municipal government in implementing spatial planning includes:

a. The setting, fostering, and supervising the implementation of regency/city spatial planning and regency/city strategic areas;

b. implementation of spatial planning for regency/municipal areas;

c. implementation of spatial planning for strategic district/city areas; and

d. cooperation in spatial planning between districts/cities. 
2. The authority of the regency/municipal government in implementing the spatial management of the regency/city as referred to in paragraph (1) letter $b$ includes:

a. regency/municipal spatial planning;

b. utilization of regency/city area space; and

c. controlling the utilization of the regency/municipal space.

3. In implementing the spatial management of strategic district/city areas as referred to in paragraph (1) letter $c$, the district/municipality regional government shall implement:

a. determination of district/city strategic areas;

b. district/city strategic spatial planning;

c. utilization of district/city strategic area space; and

d. controlling the spatial utilization of strategic district/city areas.

4. In carrying out the authority as referred to in paragraphs (1) and (2), regency/municipal governments shall refer to the guidelines for spatial planning and implementation guidelines.

5. In the exercise of the authority as referred to in paragraph (1), paragraph (2), paragraph (3), and paragraph (4), the district/municipality regional government:

a. disseminating information related to general plans and detailed spatial plans in the framework of implementing regency/municipal spatial planning; and

b. implement minimum service standards in the field of spatial planning.

6. If the district/municipality regional government is unable to meet the minimum service standard in the field of spatial planning, the provincial regional government may take steps to resolve it by the provisions of the legislation.

From the comparison of the two laws related to the authority of districts/cities, it can be seen that the provisions of Law Number 11 of 2020 have eliminated several district/city authorities including the following:
1. Implementation of district/city strategic spatial planning,

2. Determination of district/city strategic areas;

3. Spatial planning for district/city strategic areas

4. Utilization of regency/city strategic area space

5. Controlling the use of national strategic area space, and

6. Dissemination of information related to general plans and detailed spatial plans in the framework of implementing regency/municipal spatial planning.

If it is related to the principle of autonomy, the emphasis on regional autonomy should be given to districts/cities, not, on the other hand, removing or reducing the authority that is already owned by districts/cities. This is due to its relationship with communication between the government and the community in the implementation of public services where the location and the community are in the district/city. If more authority is in the hands of the central government, it is feared that this will make local governments only serve the interests of the central government and not empower the potential and communities in the regions.

When it is associated with the notion of regional autonomy as the authority of an autonomous region to regulate and manage the interests of the local community on its initiative based on the aspirations of the community by statutory regulations. Authority means rights and obligations. Concerning regional autonomy, the right implies self-regulation and selfmanagement. While the obligations horizontal means the power to administer the government as it should be, vertically means the power to run the government in an orderly state government bond as a whole. The abolition of district/city regional authority indirectly eliminates the regional authority to regulate and manage itself which is the essence of regional autonomy.

As previously mentioned, the authority granted by the central government, especially to the Aceh Government, is clearly stated that in addition to the authority determined as the authority of the Central Government, it is the authority of the Aceh Government, there is a very large opportunity for Aceh to develop the potential and uniqueness of its region so 
that it grows and develops faster so that the goal from the granting of autonomy so that regions can be independent to develop according to their potential can be carried out properly which later on the welfare of the people in the regions can increase so that what is the state's goal related to improving general welfare as referred to in the preamble of the 1945 Constitution can be achieved.

District/city-regional government is a government that deals directly with the people, especially concerning issues of public service and welfare, the development of democratic life, and justice. Decentralization or delegation of greater authority should be given to the region to open up opportunities for the local government to carry out creativity and breakthroughs for the benefit of the local community.

If it is associated with the notion of autonomy as freedom or independence but not independence, where limited freedom or independence is a form of providing opportunities that must be accounted for, and regional autonomy is a sub-system of national government organized by the central government, local governments should not be allowed to do so. break away from its relationship with the central government (Rauta, 2003). The meaning of this relationship is the existence of guidance and supervision from the Central Government.

The central government functions to carry out continuous supervision, coordination, monitoring, and evaluation as well as facilities in the form of providing opportunities for convenience, assistance, and encouragement to the regions so that the implementation of autonomy can be carried out effectively and efficiently, not by removing the authority that has been given to the regions.

Independence in the framework of autonomy and supervision in the implementation of autonomy is an inseparable unit. The implementation of autonomy that does not or does not heed the aspects of supervision will lead to an anarchic situation that can disrupt and endanger the concept of a unitary state. On the other hand, the implementation of autonomy which is supervised too closely by the central government will eliminate the essence of independence and this situation, in turn, leads to a centralized system of power. Supervision is the "binding" of the unit so that the pendulum of autonomous power does not move too far so that it reduces and even threatens unity (Bagirmanan, 1994).
Supervision of regions according to their nature can be distinguished in preventive supervision and repressive supervision. Preventive supervision is in the form of giving ratification or not giving/rejecting ratification. Following its nature, preventive supervision is carried out after the regional head's decision is made, but the decision has not yet taken effect. In other words, a regional decision in a broad sense, including a regional regulation that is subject to preventive supervision, can only come into force if the decision is first ratified by the competent authority to ratify it (Soejito, 1983).

Related to repressive supervision, the implementation is in the form of suspending the enactment of a regional decision, and or canceling it. The reason for using repressive supervision is because regulations or decisions made by the regions are considered to be contrary to higher laws and regulations or contrary to the public interest.

The pattern of supervision in the implementation of regional autonomy is mainly related to spatial planning that should be carried out by the central government towards the regions, not on the contrary removing the authority possessed by regions related to spatial planning as stated in the Job Creation Act. Supervision needs to be carried out to protect the interests of the state or the law, the interests of the province or district/city, and the interests of the population if there are regulations made unilaterally, impartial or wrong.

\section{CONCLUSION}

The provincial authority related to spatial planning regulated in the Job Creation Law has significantly eliminated some of the authority held by the province, including those related to the authority to regulate, develop, and supervise as well as the implementation of spatial planning for provincial strategic areas, the authority to determine the area, spatial planning regional space, utilization of regional space and control of spatial utilization of provincial strategic areas and provincial authorities in the framework of compiling guidelines for the implementation of spatial planning at the provincial and district/city levels. Likewise, the authority that was previously the authority of the district/city was also removed including the authority related to the implementation of district/city strategic spatial planning, determination of district/city strategic areas, spatial planning of district/city strategic areas, utilization of district/city strategic area space, control of spatial use. national strategic areas, and Dissemination 
of related information with general plans and detailed spatial plans in the framework of implementing regency/municipal spatial planning. Thus, it can be concluded that the Job Creation Act in its approach uses autonomy politics more towards centralization than the tendency towards decentralization. The abolition of district/city regional authority indirectly eliminates the regional authority to regulate and manage itself which is the essence of regional autonomy.

\section{REFERENCES}

Basah, S. (1986) Tiga Tulisan Tentang Hukum, Armico, Bandung.

Dawud, J. (2016). Penguatan Desentralisasi Asimetris Dalam Mendorong Peningkatan Efektivitas Otonomi Daerah Di Indonesia, Artikel, www.lan.go.id, diakses tanggal 10 Agustus 2016.

Karnesih, E. (2004). Desentalisasi Dalam Administrasi Negara, Jurnal Sosiohumaniora, VI. 6, No.3, November.

Krisna D., Darumurti, Umbu R. (2003). Otonomi Daerah Perkembangan Pengaturan dan Pelaksanaan, Bandung: Citra Aditya Bakti.
Manan, B. (2002). Menyongsong Fajar Otonomi Daerah, Yogyakarta: Pusat Studi Hukum Universitas Islam Indonesia, Cetakan kedua-September.

Manan, B. (1994). Hubungan Pusat Hubungan Antara Pusat dan Daerah Menurut UUD 1945, Jakarta: Pustaka Sinar Harapan.

Mandey,R.F. (2015) "Penegakan Hukum Tata Ruang Falam Pengendalian Pemanfaatan Ruang Yang Dilaksanakan oleh Pemerintah Daerah Provinsi Sulawesi Utara”, Jurnal Lex Administratum, Vol III/No.4/Juni/2015.

Nur Ervannudin dan Bimo Widodo, W. (2016). Desentralisasi Pendidikan dan Peran Aktif Masyarakat Menuju Pendidikan Berkualitas, Jurnal Penelitian, Vol.10.N0,1 Februari 2016. https://doi.org/10.21043/jupe.v10i1.866

Supriady Bratakusumah, D., Dadang Solihin, (2004). Otonomi Penyelenggaraan Pemerintahan Daerah, Gramedia Pustaka Utama, Jakarta.

Soejito, I. (1983). Pengawasan Terhadap Peraturan Daerah dan Keputusan Kepala Daerah, Bina Aksara, Jakarta.

Soemantri, S. (1981). Perbandingan Hukum Tata negara, Rajawali, Jakarta.

Wajong J. (1975). Asas dan Tujuan Pemerintahan Daerah, Jambatan, Jakarta.

Received on 20-10-2021

Accepted on 10-12-2021

Published on 15-12-2021

https://doi.org/10.6000/1929-4409.2021.10.180

(c) 2021 Arnita et al.; Licensee Lifescience Global.

This is an open access article licensed under the terms of the Creative Commons Attribution License (http://creativecommons.org/licenses/by/4.0/) which permits unrestricted use, distribution and reproduction in any medium, provided the work is properly cited. 